\title{
The institutional matrices theory as the basis of explanation of real estate bubble
}

\section{Introduction}

Real estate bubbles have occurred in many countries over the last few years. Therefore it is still a very popular and widely explained topic. A lot of authors in their researche try to implement the way of explanation based on the wide range of outlooks often beyond the economy, linking different sciences such as a law, a psychology or biology. Multiplicity of perspectives during the explanation process is the best evidence of complexity of the real estate bubble. The purpose of the article is the explanation of the real estate bubbles which were observed in the United States, Spain and Poland and were disastrous for their economies. The cognitive clarification of such complex process was done on the ground of new institutional economy. This article explains the factors which create the increase beyond the fundamentals using Novosibirsk School of Economic Sociology and Svietlana Kirdina's institutional matrices theory. The research has been performed on the set of institutions conductive to the formation of bubbles. The combination of dominant and complementary institutional matrix crucial for the creation of enormous price growth has been identified and described. The following hypothesis has been formulated: the creation of a real estate bubble is the effect of lack of optimal combination of the dominant and complementary matrices institutions. In the research part of the article there were presented the institutions which influence the balanced structure and create the conditions for the blow of the bubble. Two main areas were examined. First, unintended effects of intervention in the market economy mechanism in the form of establishment of housing finance organizations, social housing policy, and tax and

* Wrocław University of Economics, Management and Tourism latter located in Jelenia Góra 
subsidies systems. Second, wrongly understood full "liberalization" of market and deregulation of all market processes was examined from the perspective of the creation of debt for the customers and financing banks themselves. Therefore the research was performed on the securitization process, capital requirements for banks, in the area of lending standards and new banking products.

\section{Literature review}

\subsection{Definitions}

At the beginning it is worth to define the institution. To find the appropriate definition and elements of institution it is important to underline several significant elements of institutions indicated by authors of the old and new institutional economics.

Thorstein Veblen one of the "founding fathers" of institutionalism formulates the following definition: social institutions are in essence the dominant ways of thinking, taking into account the different social conditions and certain functions of the individual and the society. [...] Each community can be seen as economic mechanism consisting of what we call economic institutions. These institutions are usual ways of life processes' regulation in the society with regard to the material environment in which it exists [38]. In this definition author divided institutions into two types: social and economic. The first are the ways of thinking, attitudes or method of recognition of social phenomenon. The second group creates economic mechanism and is the basis for the action of people in the material environment. For better understanding of economic and social order it is crucial to refer to the historically shaped institutional framework forming the specific context of human activity [5].

The second of the "founding fathers" John Rogers Commons introduced, in the place of the impersonal market exchange, characteristic for the orthodox economics, the concept of a transaction. It led to the creation of the conception which allows understanding the activities of individuals, their economic and social life with the accompanying problems. Transactions are the meeting places of economics, physics, psychology, ethics, jurisprudence and politics. They are the two or more wills giving, taking, persuading, coercing, defrauding, commanding, obeying, competing, governing, in the word of scarcity, mechanism of rules of conduct [5]. J. R. Commons stressed the importance of the regulations, state legislation and well-developed process of constituting the law. He underlined the fact that good legislation creates appropriate incentives for individuals or groups of individuals to act wisely and worthy. The law however, limits activities that are harmful [7]. 
In the new institutional economics the work of Ronald Harry Coase Noble Prize winner in 1991 should be described as the background and milestone in the direction of the transaction costs economics. R.H. Coase observation of the market shows that the transactions are not made in emptiness, but within the institutions that organized the market [6]. His approach to institutions is very broad starting from patterns of human behaviour and on the formal regulations at the various levels of social life ending. Rational individuals achieving their aims act always in the institutional environment. They need to take it into account, and even in their way of achieve goals they could try to change the rules for their benefit and also break them. This fact is the evidence that the famous institutional balance of the market structure could not guarantee perfect competition [5].

For Oliver Williamson institutions are primarily the principles and rules governing transactions which relate to the conception of the "contracting human" characterized by limited rationality and opportunism behaviour [31]. Douglass North proposed the definition of institutions as rules of the game or more formally human made constraints that shape human interaction and cooperation. As a result, build the structure of incentives in the area of exchange between people, whether political, social or economic. Institutional changes shape the way of society evolution and are therefore the key in understanding of historical changes [34]. Marshall Hodgson offered conception of institutions as a system of established and widely recognized rules in society that shape social interactions. Language, money, law, system of weights and measures, rules of behaviour at the table, companies and other organizations are within the scope of the definition of institution [17].

The presented overview of the definition does not cover probably all of the approaches to the institution. The multiplicity of definition attempts made by the wide range of authors shows the difficulty in finding single universal definition corresponding to the representatives of both the old and the new institutionalism. For the purpose of this paper presented set of definitions should be sufficient, as it highlights the main elements of the institutions that will be used in the further analysis of real estate bubble. These elements are the rules of the game in the real estate market. The first group of rules is connected with the intervention in the market economy through the establishment of housing finance organization and tax relief and subsidies for real estate purchases. The second one wrongly understood "liberalization" consists of rules at both levels: the creation of debt for the customers, but also at the stage of financing banks themselves. "Liberalization" means transferring risks through securitization process, lower capital requirements, lowering lending standards of banks such as loan-to-value ratio, long maturity period, or lack of verification of clients.

Similarly to institution also economic bubbles are not formally defined in the economics with a single universal definition which could help to identify them. 
It is mainly due to the fact that this process is very complex and occurring over several hundreds of years. Multiplicity of markets, geographic spread and variety of items influenced by bubble makes this area still poorly understood. For the purpose of this article some repetitive and generally accepted definitions and characteristics of economic bubble are discussed.

The definition of bubble most often used in economic researches is: part of asset price movement that could not be explained on the basis of fundamentals. Fundamentals are a group of variables which determine asset prices. In the situation of a specific model of asset price determination, if there are serious problems with forecasting asset prices there could be a symptom of a bubble [14].

Whenever perceived or psychological value of assets exceeds its real economic value the bubble exists. Economic value could be defined as value based on rational economic parameters, such as growth of population, growing company earnings, increased personal income, or some other fundamental economic factors directly linked with the asset's rise in value. Alternatively, if the asset is sold for a lot more than its economic value, and the price increases for two or more times by growing psychological or perceived value then it is a bubble. [40]

In the above definition the great importance of value was stressed. Value is the concept from the area of metaphysics on the ground of neoclassical economics. In mainstream of the institutional economics, value is determined institutionally and culturally. Therefore, certain behaviours and choices are fixed in the institutions and culture. Despite they do not make the value they give it or receive it [37].

The last element which will be used in explanation of real estate bubble is the idea of soft budget constraint. It was introduced by Janos Kornai in his book Economics of Shortage [28] and in his expository paper [29] briefing the theory of chronic shortage in socialist economies. The term "budget constraint" was taken from the theory of the household. The statement that the decision-maker has a budget constraint is equivalent to the Say's principle. The budget constraint is not technical relation nor book-keeping identity, but postulate of a rational planning. Two important things must be emphasized. First, the budget constraint is connected with a behavioural characteristic of the decision-maker. It is used during the decision about covering expenses from the income generated from various sources. As a result, the decision-maker adjusts his expenses to his financial resources. Second, the budget constraint is a constraint on ex ante variables and firstly on demand. It is determined by expectation concerning future financial position when the actual spending will occur [30].

The budget constraint is "softened" when the severe relationship between expenditure and earnings is relaxed, as excess expenditures over earnings will be covered by some other organization, usually by the State. An additional factor of 'softening" is that the decision-maker expects such external financial support with 
high likelihood and this likelihood is firmly built into his behaviour. J. Kornai presented for socialist firms different ways and means of softening the budget constraint. There were divided into four groups: soft subsidies granted by national or local governments, soft taxation, soft credit and soft administrative prices [30].

Subsidy granted by the governments (national or local) is soft if it is negotiable, subject to lobbing or bargaining. The subsidy is adjusted to cost overruns (past, present or future). The attribute soft in the taxation does not refer to the rate of taxation. Taxation system can be hard even with the low tax rate, if rules in the system are uniform, fixed for the long period and the payment of tax is enforced rigorously. In the system of soft taxation tax rates are not uniform, but almost tailormade according to the financial situation of different sectors or regions or forms of ownership. Soft credit is also not connected with the level of interest rate. Credit system can be hard event in the situation of low interest rates, when the fulfilment of credit contracts is severely enforced. In opposition the soft credit system means tolerance of unreliable debt service, postponement and rescheduling of credit payments. Soft administrative prices could be applied in the situation, when the price is not set by a free contract between seller and buyer, but by some bureaucratic organization. The administrative price is hard if, once set, it restricts expenditure and does not automatically adjust to cost rises [30].

\subsection{The institutional matrices theory}

On the ground of the system paradigm which deals not just with the individual details of economy but with the system as a whole has been developed by Svietlana Kirdina the institutional matrices theory. Institutional matrices theory follows traditional Russian economic way of thinking and stands apart from western theories [24]. The most significant reason of a new theoretical framework construction was driven by the insufficiency of actual structures for understanding and predicting social processes [25].

Theory of institutional matrices is founded on two key postulates playing the role of axioms. The first is a vision of society as an integral, indivisible object. The economic process should not be clarified only on the basis of data which characterize economy in its substantive meaning. Economic processes explanation requires also reference to political (organizational) and value (motivational) aspects. The second theory postulate is assumption about basic institutions. Basic institutions are described by as historically stationary, very deeply rooted, and perennially reconstructed social forms. They were called as historical invariants allowing the society to survive and advance during historical evolution without losing its self-sufficiency and integrity. Basic institutions are independent of concrete social actors' desire and will. The basic institutions category (distinct from 
a broader category of "institution") abstracts from social relations only historically stationary and internally unchangeable. Their function is regulation of social subsystems and the maintenance integrity of societies of different types [24].

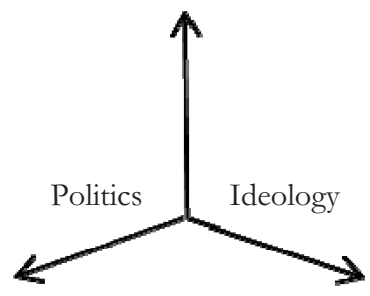

Economics

Figure 1. The main projections of the society

Source: [23]

On the basis of stated assumptions the model of human society as a social system structured along three axes: economy, politics and ideology could be now elaborated on (see Figure 1). These three spheres are strongly interrelated morphologically as sides, parts or elements of an indivisible whole [23]. The system approach to society makes it possible to identify economy, politics and ideology as the subsystems [24].

The economic sphere of society relates to the receipt of resources used for the reproduction of social entities. The political sphere is connected with interrelations for regular and organized civil and public society actions which purpose is to achieve defined local, regional or national aims. Finally, the ideological sphere is connected with the interrelations embodying significant cultural and social ideas and values of a nation of people [22].
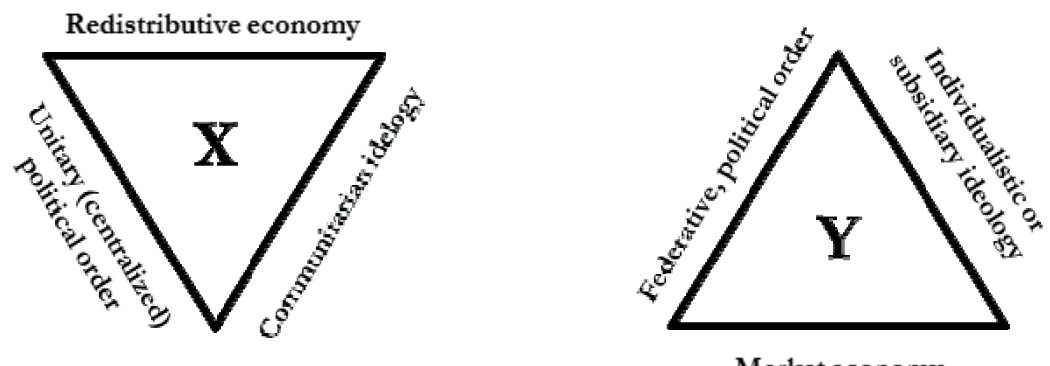

Figure 2. Institutional $\mathrm{X}$ - and Y-matrix

Source: [23] 
The corresponding set of basic institutions regulates each of described spheres. Empirical studies and historical observation as well as mathematical modelling and a wide philosophical approach constitute a ground for the following hypothesis: two specific interdependent types of institutional matrices exist around the world. They are called X-and Y-matrix and are presented in Figure 2 with their unique identities of each one in relation to the other. The matrices are different in function of the set of basing institutions creating them [23].

The X-matrix can be described by the following set of basic institutions. In the economic sphere institutions of the redistributive economy which is characterized by the existence of centre (on the top). The centre controls the movement of goods and services and also regulates the rights for their production and use. The political sphere consists of institutions of a unitary (unitary-centralized) political order). The ideology projection is created by the institutions of communitarian ideology, whose essence is described by the idea of domination of collective, shared, public values over individual, sovereign, private ones. The priority of "We" over "I". [9]
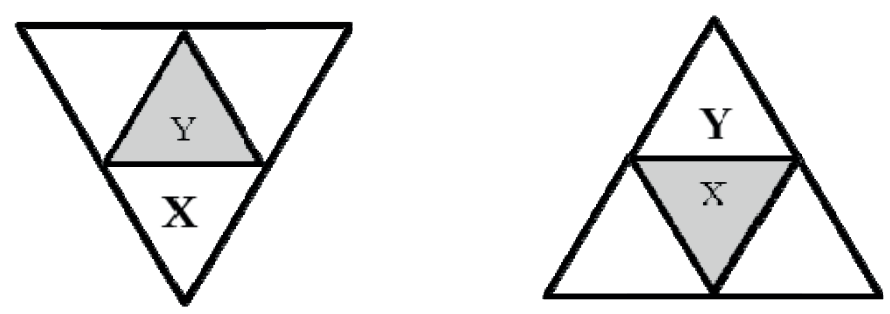

Figure 3. Combination of dominant and complementary institutional matrices Source: [23]

In the Y-matrix the basic institutions in the economic sphere are the institutions of a market economy. Political institutions are connected with the federative (federative-subsidiary) political order. Finally, the ideological institutions consist of an individualistic (or subsidiary) ideology, proclaiming the supremacy of individual values over the values of larger communities, bearing a subordinate character to groups and the personality. The priority of "I" over "We"[23].

In modern societies and nations, $\mathrm{X}$ - and Y-matrices interact, with one of them permanently predominating. Nevertheless, the matrices are not exclusive entirely of each other. Both $\mathrm{X}$ and $\mathrm{Y}$-matrices co-exist simultaneously in any given case. In other words, the society social structure can be described as a dynamic binary-conjugate structure of these two interrelating, yet alternative institutional complexes. The supremacy of one matrix over the other is usually constant in the course of history. The dominant institutions of the prevailing matrices therefore play a role of a performance framework for complementary institutions from the other matrix as it is presented on the figure 3 [23]. 


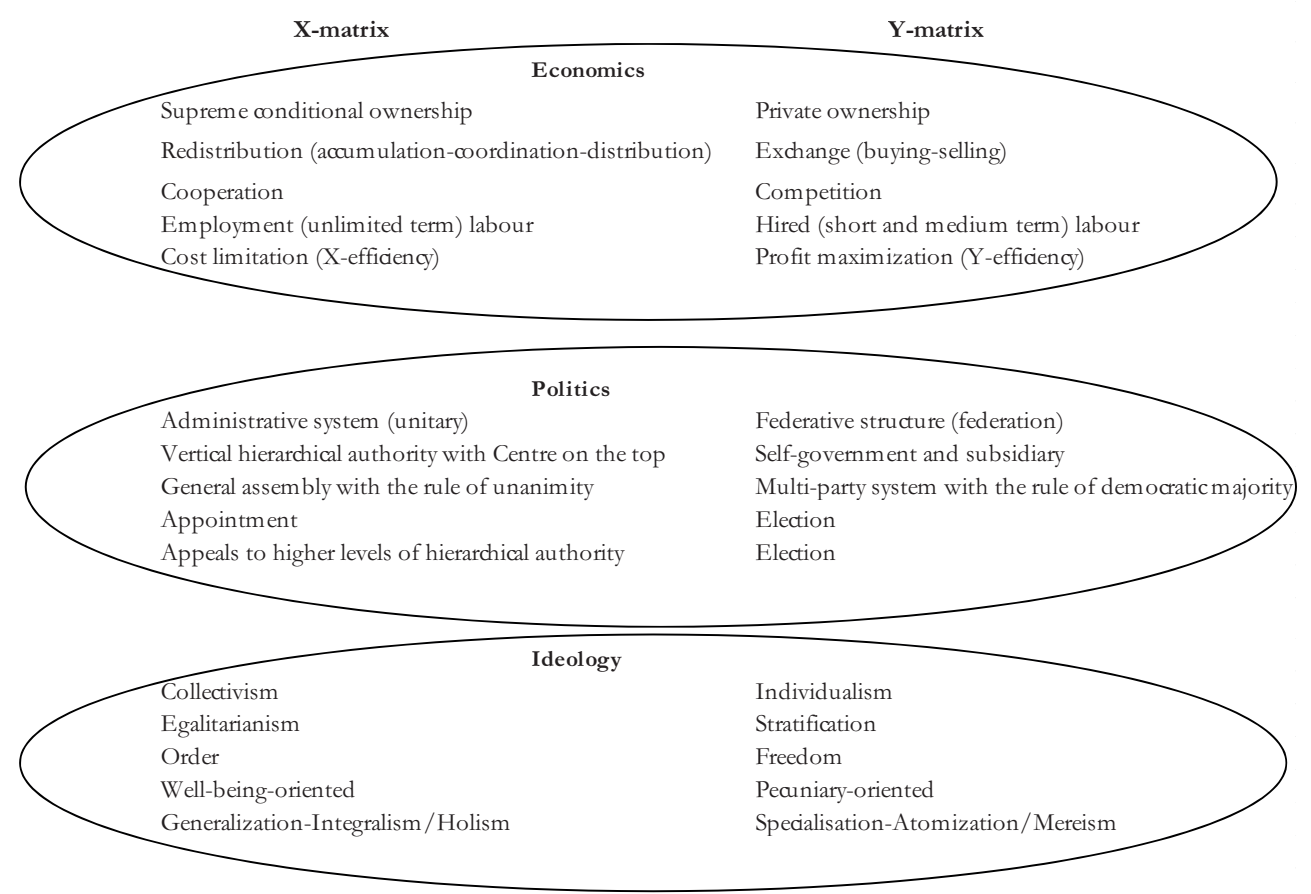

Figure 4. Institutions of $\mathrm{X}$ - and $\mathrm{Y}$-matrix and their functions

Source: [23]

The X-matrix institutions are predominant in China, Russia, and India along with most Latin American and Asian countries. In these cases Y-matrix institutions are "a must" but they have additional and complementary functions. Conversely, Y-matrix institutions prevail in most European countries and in North America, whereas X-matrix institutions are supportive. On the Figure 4 the structures and functions of basic institutions in X-and Y-matrices through each of three spheres are presented [23].

\section{Institutional analysis of real estate bubble - empirical research}

In the research about real estate bubble the institutional basis could not be ignored. It is crucial to take into consideration institutional factors, due to the fact that in the early stages of formation of economic bubble, prices are raising 
as a result of logical and economically justified reasons. For example, the cause of increase in the prices of houses can be a growing population. When the number of people reporting the demand for houses is increasing and the supply is relatively stable or growing at a slower rate, increase in prices appears to be economically justified. Prices may also rise due to increased income and in the situation of limited supply. In this situation the price is again the result of demand and supply. Therefore, irrespective of how expensive the houses are, as long as economic justification for higher prices could be found in reference to the fundamentals, the price increase is not a bubble. However this mechanism is often disturbed when there is a crisis of institutions in the area of factors influencing the price increase.

In order to explain the real estate bubble process it is important to identify the prevailing combination of institutional matrices on the ground of the presented institutional matrices theory. It is obvious that without institutions of a market economy in the economic sphere, the institutions of federalism in the political area and ideology of individualism, there would not be the real estate bubble. Clearly, as it has been already mentioned, it has never been the pure X- or Y-matrix. Therefore, the environment for real estate bubble is the combination of two matrices with the domination of Y-matrix with its set of basic institutions. The basic institutions of Y-matrix are some kind of underlying (necessary) conditions in creation of the growth beyond the fundamentals. However they could not be seen as the only cause of their formation. Referring to the previously described definition of economic bubble it should be noted that basic institutions of Y-matrix allow the creation of sustainable growth of prices which could be distorted and turned into speculation with the end in disastrous bubble economy. The examples of such kind of distortion are presented in the research part of article in two groups: unintended effects of intervention in the market mechanism and wrongly understood full "liberalization" of market and deregulation of all market processes.

\subsection{Unintended effects of intervention in the market mechanism}

One of the key factors contributing to the formation of real estate bubble is intervention in the market mechanism affecting the balanced proportion of basic institutions of a dominant and complementary matrix in the economic system. There are many examples of intervention in terms of real estate market. The most significant in terms of repercussion in the economy have been examined in this article.

The first and foremost example of intervention was the establishment in the United States of America two sources of housing finance: The Federal National Mortgage Association (Fannie Mae) and The Federal Home Mortgage Corporation (Freddie Mac). The organizations were chartered by Congress of the United States 
to create a secondary market for residential mortgage loans. President Franklin Delano Roosevelt created Fannie Mae in 1938 as part of New Deal program. The main purpose was to help jump start the national housing market after the Great Depression. Freddie Mac could be characterized by the much shorter history, due to the fact that it was founded in 1970 [15]. Mission of both organizations was to help working families access to long-term mortgage or providing to them quality rental housing. The objective of organizations was to create a system for stabilization the home mortgage market, increasing the possibility of buying and rental for the less wealthy Americans [13]. In addition, they were involved in supporting families who have problems with self-payment of the mortgages. Thus secure many people from losing their homes. At the time when the loan was not repaid they took the obligation to sell the property on their own at the price close to market value [35].

Assets hold by them - through mortgage securitizations and direct portfolio holdings - have increased from approximately $7 \%$ of total residential mortgage market originations in 1980 (about 78 billion dollars) to about $47 \%$ in the year 2003 (3.6 trillion dollars). By the year 2010, Fannie Mae and Freddie Mac owned or guaranteed about half of all outstanding mortgages in the United States, including a considerable share of sub-prime mortgages. They financed $63 \%$ of new mortgages originated that year. Other federal agencies, such as the Federal Housing Administration and the U.S. Department of Veterans Affairs, insured another $23 \%$ of home loans. Therefore it means that federal taxpayers guaranteed approximately $86 \%$ of all new mortgage originations in 2010 [32].

The involvement of the organizations equity-related with the government of the United States was an important factor of creation the housing bubble. Guarantee of mortgages for the insolvent individuals without creditworthiness was some kind of J. Kornai's softening budget constraint. The overall objective of Fannie Mae and Freddie Mac has not been achieved.

The evidence of this is an analysis performed on the basis of data about sales prices of new homes sold in the United States [1]. As presented on the figure 4 between the years 1969 and 1970 it was observed the decline of the median sales prices of new homes from 25600 to 23400 dollars in the year of establishment of Freddie Mac. In the period of first ten years of activity of this organization there was a significant increase of sales prices median for about $176 \%$ in comparison to the year 1970. For better understanding of this trend the growth of prices between 1963 and 1970 amounted to only 30\%. It must be underlined that the first few years after the establishment of the organization, annual increases ranged from a few to several per cent reaching the peak between 1972 and 1973 at the level of $18 \%$. In light of these trends the overall aim of Freddie Mac and Fannie Mae has not been achieved and the huge increases since 1970 were the unintended effects of intervention in the market mechanism. 
Moreover, during the first five years of the twenty-first century, growth in median sales price of new houses has reached enormous proportions. During this period the median increased for about 43\% from 169000 dollars in 2000 to 240900 dollars in 2005. This trend, however, has not been maintained for a long time and in the next two years there were seen growths for only $1-2 \%$. These increases preceded the collapse of the property market in 2008 and 2009 with the decreases reaching the levels of 6 and $7 \%$.

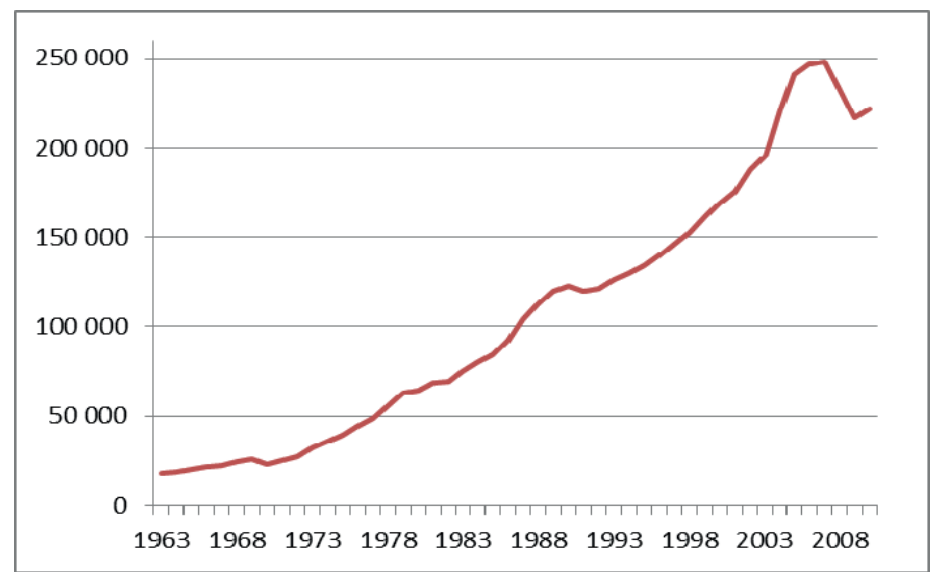

Figure 5. Median sales prices of new homes sold in the United States between 1963 and 2010

Source: own elaboration based on [1]

The culmination point of a very long-lasting period of boom in the property market was the increase of involvement of Fannie Mae and Freddie Mac into the support of insolvent borrowers. In the first period of the 90 s the maximum amount of debt, which was granted to the American family with an average income amounted to about 90 thousand dollars. Ten years later the amount of granted debt increased to 200 thousand dollars. Taking into account a growth of house prices in the decade of 90 s of approximately $31 \%$ the increase in granted debt had no economic explanation [35].

In connection to the subject of this paper organizations established in order to stabilize market mechanism in the area of mortgage loans could be seen as the framed within basic institutions characteristic for the X-matrix. Due to the lack of strict rules based rather on economic factors such as creditworthiness they become a tool of speculation and led to the blow of enormous real estate bubble. The idea of founding this kind of stabilization organizations in the intention 
was not bad. However, Fannie Mae and Freddie Mac guarantees and secure the mortgage without taking into consideration the strict, healthy criteria. Taking over more and more debt and engagement in the huge credit actions, without expectation of discipline in debt service and a hope of repayment of debt was a departure from the basic institutions of Y-matrices. Ideological basis of activities of these organizations involving the support for less wealthy part of community was closer to the principles of collectivism and well-being-orientation rather than individualistic thinking directed for the maximisation of profits. In effect, subsidizing such activities under the motto of stabilization of real estate market had to failure because it has become a field for fraud and moral hazard in situation where everyone could borrow money in the hope that the debt will be taken over by the government supporting organizations.

The examination of Polish and Spanish mortgage market does not provide the evidence of intervention in the market mechanism in the scale similar to the United States. However the performed examination of these markets shows important institutions characteristic for the X-matrix as a part of social housing policy of these countries. The first observed in Poland is connected with the National Strategy for Social Policy for the years 2007-2013 (as a part of the National Development Plan). The aim of this policy was prevention against social exclusion in the context of access to housing. It was done through improvement of the financial framework of affordable rental housing program and development of affordable rental dwelling co-financed by preferential loan granted from National Housing Fund resources (located in National Economy Bank - BGK). The preferential loans were granted for Social Building Association (TBS) and housing cooperatives for building and adaptation for rental. The flats financed with the participation of National Housing Fund were rented to families who do not own the legal title to another flat, as well as those who have a moderate income per head in the family.[10] Spanish Ministry of Housing has created a National Plan for housing and renovation with the perspective of 2009-2012. The purpose of the plan was the elimination of barriers of access to houses by Spanish households connected mainly with the difference between the market price of house and economic capacity of households. It was done on the ground of social aim stated by the Spanish Constitution: creation of necessary conditions for a decent and suitable home to live for everyone, which is the right especially for those citizens with economic difficulties and lower-income groups [11]. This aim is strictly connected with the mentioned collectivism as an X-matrix basic institution in ideology sphere.

Another form of intervention in the market mechanism in Poland was the system of subsidies which was available till the end of the year 2012. The 50\% of mortgage interest payments (calculated on a reference rate basis) could be 
subsidies for a period of 8 years according to the "Act for the Finance Assistance of Families in the Purchase of Their Own Flat". The scope of the subsidies was restricted to the flats and single-family dwellings with the certain disposable area. In addition, the mortgage loans under this program must be denominated in polish zloty and there were also restrictions in connection with the price of the dwelling [10]. This kind of subsidies in connection with the real estate market significantly influenced the decision about purchase of new flats and was an additional factor of enormous price increase.

Another form of intervention in the real estate market mechanism which was observed in was a tax deductions and subsidies system. Amendments to the Law on Personal Income Tax, which entered into force on January 2007 in Poland led to the liquidation of interest relief, and thus limited the intervention in this area. However, all tax payers who took out mortgages to the end of 2006 may still benefit from the deduction of interest on these loans. Tax deduction mechanism is the ability to deduct from the tax base actually incurred paid interests on debt granted for the housing needs. The relief was intended as kind of intervention in the housing market as a possible deduction increased, in fact, real borrower's ability to pay the mortgage debt. It was an incentive for the decision about buying new house.

In the Spain in the period of real estate bubble the mechanism of mortgage tax relief made mortgage repayments tax deductible. Mortgage tax relief was available for loans on primary residences. The tax deduction amounted to $15 \%$ of the mortgage payments up to an annual limit of 9.015 euros, giving the maximum amount of annual savings of 1.352 euros [21].

The mechanism of tax credit was used in a much larger scale in the United States. It has found its source in the approved by President Herbert Hoover Federal Home Loan Bank Act of 1932 with the aim of providing liquidity to mortgage lenders. Designed relief has been a repeatable subjected to criticism, but as a part of incentive and stimulation system in the real estate market has not been reformed for a very long time. The main reason was that it was an essential part of real estate market development and incentive to achieve "American Dream". Interest deduction was a very expensive way to support the property market because it costs annually more than 20 billion dollars in the period between the year 2000 and 2007 [16].

In connection to the research carried out in the article [8] available at HousingEconomics.com about beneficiaries of tax deductions in the property market in America it must be emphasized that the main recipients of these incentives were in 2008 the middle class taxpayers with the income in the range of 50 000 to 200000 dollars. This could be the confirmation of emerging criticism on this kind of intervention. The tool that was intended to promote the purchase 
of real estate assets by less wealthy part of society, in fact, has become supporting tool of speculation. It was the primary contributing factor in the creation of American housing bubble. It has awarded the highest subsidies, in the form of tax deductions of up to a million dollars to the richest one third of Americans willing to buy the biggest and most expensive houses, while rejecting subsidies to the two thirds of American income earners who cannot buy a house at all or who cannot take advantage of the housing deduction due to the fact that it does not exceed their standard deduction granted to all taxpayers [16].

The average size of houses bought by Americans has grown from 949 square feet in 1900 to 2436 in 2005 [16]. With reference to the theory of institutional matrices an intervention through tax deductions reflect activities characteristic for the basic institutions of X-matrix. There were intended to be a help in achieving the general welfare and availability of house for everyone even less wealthy citizens of the United States. However, the inappropriate design of the deduction works for the one third of wealthiest Americans and again support rather speculative activities conducted by them. As the support of these it is worth to see into the Table 1 which shows the comparison of home ownership between various developed countries which introduced or not the tax deduction system. The analysis of the data shows that such developed countries like the United Kingdom or France have reached high home ownership rate in 2001 equal or even higher than the United States, without the expensive system of tax deduction. The aim of higher home ownership rate could be achieved also by other, less expensive ways.

Table 1

Comparison of home ownership between developed countries

\begin{tabular}{|l|c|c|}
\hline \multicolumn{1}{|c|}{ Country } & $\begin{array}{c}\text { Tax deduction for } \\
\text { housing }\end{array}$ & $\begin{array}{c}\text { Home ownership } \\
\text { rate in 2001 } \\
\text { [\%] }\end{array}$ \\
\hline United States & Yes & 69,0 \\
\hline United Kingdom & No & 71,1 \\
\hline Germany & No & 43,6 \\
\hline France & No & 63,1 \\
\hline
\end{tabular}

Source: [4]

The tax deductions system and subsidies in the real estate sector as the tool of stimulation is the soft budget constraint in the J. Kornai meaning which influences the balanced combination of institutional matrices. 


\subsection{Wrongly understood full "liberalization" of market and deregulation}

In the last part of this paper the real estate bubbles are explained taking into consideration wrongly understood full "liberalization" and deregulation of all market processes. As an element of this process, especially connected with credit system, soft budget constraint is described on the basis of available evidence in the examined countries. There are identified and described most visible and important aspects of soft budget constraint. In connection to the institutional matrices theory there are presented cases in which there were attempts to eliminate, from the combination of matrices, the complementary matrix. It was performed in order to create a system of domination of Y-matrix. It is in opposite to the discussed intervention in the market mechanism when the prevailing matrix attempted to be dominate was the X-matrix. Aspiration for absolute deregulation was the source of many deformations in healthy functioning market system such as lowering lending standards, an increase in lending on a large scale in many countries, securitization process and other things leading to the creation of moral hazard.

Following behind Grzegorz Kolodko the reasons of such negative events as financial crisis and economic bubble could be found in the isolation of the financial sphere from the real economy [26]. The financial sphere was out of control, as a consequence of liberalisation of financial markets. On the way to the ideological freedom and in the process of embedding of freedom in the market economy, at both the creation of debt for the customers, but also at the stage of financing banks themselves, was a high deformation of market system, and unbalanced structure of the combination of basic institutions. As the result of this process there has been a very dynamic development of financial instruments, including the securitization process.

Securitization is the process which allows banks to turn traditionally illiquid financial assets (bank loans) into the marketable securities. The most popular method of conversion of loan into tradable security was mortgage backed securities (MBS) and collaterized debt obligation (CDO). Securitization allows funding lenders to transfer the risk connected with loan and increase their liquidity by selling it in the secondary market as a parcel of loans [16]. The consequences of securitization were several. First, the symbiotic relationship between lender and borrower has been broken. Banks historically keep the mortgages on the books and service the loan directly (keeping a relationship with the borrower). Securitization allows to separate mortgage origination from mortgage servicing. Therefore originators of loans had no longer a vested interest in the viability of a borrower in a long-term. It led to definitely lower lending standards. Moreover, 
it allowed banks to issue more loans than their balance sheet might otherwise. Secondly, securitization made very difficult dealing with problem loans. It was due to the fact that mortgages were in pools with cash flows allocated according to a prearranged dynamic. As a result no one party were in charge of a particular mortgage. Previously borrower was able to negotiate directly with the bank holding mortgage, securitization made potential loan modifications through negotiation almost impossible [33].

Table 2

Securitized subprime loans

\begin{tabular}{|c|c|c|}
\hline Year & $\begin{array}{c}\text { Total mortgages } \\
\text { that were sub- } \\
\text { prime } \\
{[\%]}\end{array}$ & $\begin{array}{c}\text { Subprime mort- } \\
\text { gage that were } \\
\text { securitized } \\
{[\%]}\end{array}$ \\
\hline 2001 & 7,8 & 54,1 \\
\hline 2002 & 7,4 & 62,9 \\
\hline 2003 & 8,4 & 61,1 \\
\hline 2004 & 13,5 & 75,7 \\
\hline 2005 & 21,3 & 76,3 \\
\hline 2006 & 20,1 & 74,8 \\
\hline
\end{tabular}

Source: [16]

The significance of the securitization process in the creation of the real estate bubble was visible in the United States and Spain. The increasing level of securitization in the United States is shown in the Table 2. In 2006 20\% of mortgages were subprime and 75\% of them were securitized. In 2006 value of the subprime mortgages amounted to about billion dollars which was about $8 \%$ of Gross Domestic Product on the peak of economic growth of the United States [36]. Spanish Mortgage-Backed Securities (SMBS) regulated in 1992 were very popular and after the ten years Spain was the third issuer of MBS in Europe [2]. In 2010 value of all securities (mortgage-backed and assets-backed) was so high that the Spain reached the second place in Europe as an issuer [3].

The development of the securitization process in Poland has been strictly connected with the progress of law regulations in this matter which was significantly delayed in comparison the changes in the Polish financial market. The Polish banking sector has not been interested in the process of securitization for a very long time mainly due to the lack of formal definition of the process, regulations in the banking law or limitation in transactions conducted by the 
securitization fund [39]. According to the report from 2013 the market of securitization does not practically exist in Poland. In the last several years there have been realized by banks only two important transactions which have not been connected with the mortgage loans [19].

The main problem with the new financial instruments and securitization process especially visible in the United States was involvement of banks which activity were deregulated mainly in the area of connecting the lending (commercial) and investing banking (abrogation of the Glass-Steagall Act). What more, in the process were also engaged the organizations which have never been regulated. The system called by Paul Krugman as the system of "shadow banking" exaggerated the conventional banking system [31]. Lack of regulations in this part of economy led to an unbalanced combination dominated by Y-matrix institutions with the aim of maximisation of profits, especially by lenders and Wall Street financial institutions such as hedge funds and money funds. It was a mechanism of transferring risk connected with bad debt and softening budget constraint by banks and similar institutions. This process accelerated the financing of the real estate bubble and also supports the speculative activity.

The next evidence of softening budget constraint from the perspective of commercial banks was connected with the capital requirements. Loosening standards and aggressive lending led in the United States to decreasing capital requirements. In 1990 the capital requirements amounted to 10\% whereas in the year 2005 it was only 2,5\% (minimum capital requirement for Freddie Mac and Fannie Mae). Comparing capital requirements of the United States with the United Kingdom and BASEL we can see that the difference was considerable. They set the requirements at the level of $8 \%$ [16]. As a result another accelerating mechanism has been launched under the deregulation trend. The decline in capital requirements exposes banks on the high level of unjustifiable risk.

Further signs of softening budget constraint in the United States could be found in the commercial banks operations growth. Through acquisition at the end of 2002, there were 7887 government-insured commercial banks in comparison to 12347 in 1990. The level of acquisition sprees in the commercial and investment banking sector in the late 90s led to creation of lending behemoths seriously dependent on economies of scale. During the last real estate boom in the United States the mortgage industry was heavily relied on human capital and expensive technology. The loan origination process was based on the hightechnology platforms connected with millions of dollars investments. Due to the high level of fixed costs, the profit of originators depended more on volume than quality [16].

From the borrowers' perspective soft budget constraint (soft credit) is visible when lenders began relaxing lending standards and loan approval guideline. 
One of the primary lending standards is the level of loan-to-value ratio (LTV). Higher level of ratio means higher risk exposure of a bank. Each bank has its own limits of this ratio and in the situation of exceeding this ratio higher down payment is required. Safe level of this ratio is when it is below $80 \%$. During the boom on the real estate market in Spain the LTV amounted to about 64\% [12], however there are still available sources of offers of banks from 2010 with the ratio $100 \%$ [18]. The average value of LTV in the United States increased from $88 \%$ in the middle of 90 s to $94 \%$ in 2005 [9]. In Poland in the period of boom most of credits were granted with the ratio between 75 to $100 \%$. In 2010 there were situations when the credit was granted for the $120 \%$ of the value of property. In the Alior Bank S.A. proposal there were credits with LTV at this level [20]. However, the Polish Financial Supervisory Authority implemented several recommendations regarding mortgages such as the calculation of creditworthiness, the limitation of credits in foreign currencies etc. [27]. These recommendations had a significant influence on the creation of mortgages. They protected Poland against the blow of speculative real estate bubble.

The second important credit standard is the maturity of the credit. The research performed in each of the examined countries shows that in the period of boom on the real estate market the maturity period was extended and there were credits with the maturity period above 30 years (with the maximum maturity of 50 years). Margins and other charges connected with mortgage loans (low down payment etc.) were in the period of enormous real estate price increase on the risky low level. The main reason of that fact was a wish of further acceleration of credit action by banks and desire of joining to the group of beneficiaries of rising market.

The signs of relaxing approval guidance are visible in the United States in the form of the stated-income loan. This loan was traditionally extended to borrowers who could not confirm their income due to the fact that they were selfemployed or did not want to generate income tax returns for personal reason. It was used by lenders as a standard also for the borrowers with easily verified income (including fixed income) [16].

Other products with the feature of soft budget constraint and avoidance of regulations were stated asset loans, no-ratio loans and no-documentation loans. Generally a prime loan has the requirement of verification of assets to cover 2, 5 or 12 months' worth of mortgage payments which should be available to the borrower. In the state asset loan, the borrower was obliged only to state the amount of assets, not verifying them. In a non-ratio loan, the income of the borrower was not disclosed; the underwriter decided whether the person's business, position and tenure suggest they can repay the loan. No-documentation loans were probably the softest products. The borrower did not even state his occupation and the underwriting decision was based entirely on his credit history and collateral [16]. 
The institutional matrices theory as the basis of explanation of real estate bubble

All above factors led to the unbalanced structure with the dominant Y-matrix with the wrongly understood freedom in terms of banking practices and standards. This unbalanced institutional combination was the field for the moral hazard and accelerator in blowing the enormous increase in properties prices.

\section{Conclusion}

The creation of a balanced institutional structure with the optimal combination of the dominant and complementary institutions positively influencing economic growth and preventing against deformations such as an economic bubble is very challenging and hard work. The combination completely dominated by one of the matrix leads to crisis and stagnation. When the market does not work effectively it is supplemented by the institutions on the ground of monetary and fiscal policy. On the other hand, the efficient market means the private ownership, exchange, competition, freedom and ideological individualism.

Results of the research discussed in this paper show that real estate bubble was created in the environment of combination of two matrices with the domination of Y-matrix. Basic institutions of that matrix were necessary conditions for development and growth in the real estate market. The study shows that in the examined cases the development and market growth was repeatedly distorted and turned into situation when the perceived and psychological value of houses exceeds their economic value. The identified institutions which influenced balanced structure and supported the blow of the bubble were divided into two main groups.

First group, unintended effects of intervention in the market economy mechanism, was against the dominant matrix and was planned as the response for the needs of less wealthy part of society or the way of stabilization and/or stimulation of real estate market. The overall objectives of interventions in the examined cases have not been achieved. The best evidence of that fact was an enormous increase in houses prices in the first years after establishment of Freddie Mac. The efficiency of tax deductions and subsidies as the way of stimulation of real estate market was also questioned due to the fact that higher ownership rate was achieved in several countries without such expensive system reliefs. Besides, this mechanism was used mainly by wealthiest part of society which was in conflict with the basic assumptions of the program. In all the presented cases of intervention in the market mechanism, established with good intentions, the result of the intervention was the creation of mechanism finally supporting the speculation and blowing the bubble. The main reason of that fact was connected with the inappropriate design of the institutions of complementary matrix. In the case of 
organisations Fannie Mae and Freddie Mac the problem was that they guaranteed and secured the mortgage without taking into consideration the strict, healthy criteria. As a result their activities become a field of fraud and moral hazard, creating situation where everyone could borrow money in the hope that the debt will be taken over by someone else. The conclusion for this group of institution based on the research is that it is crucial in the case of dominance of Y-matrix to create the safe system of complementary institutions which are protected against such speculation and moral hazard.

The second group wrongly understood full "liberalization" and deregulation of all market processes through softening the budget constraint, was in line with the dominant matrix institutions and was planned as a tool for stimulation of the real estate market. This group was called as wrongly understood full "liberalization" with reason. It shows that liberalization in each of examined cases was a desire to eliminate of the complementary matrix from balanced institutional structure. "Wrongly" means that liberalization is possible in the healthy economy however it does not mean that market mechanism could work without any institutions. Therefore, deregulation in each of examined cases led to isolation of financial sphere from the real economy. It was done at the level of lenders (banks) through softening budget constraint in the process of securitization or decrease of capital requirements and also at the level of borrowers through softening budget constraint by lowering lending standards such as loan-to-value ratio, maturity period or fees and charges connected with credit or relaxing the loans' approval guidance by banks in the no-ratio and nodocumentation loans.

\section{References}

[1] Bureau of the Census, United States, http://www.census.gov/const/uspriceann.pdf (09.06.2013).

[2] Bucholski R., Sekurytyzacja aktywów banku bipotecznego, Prace Instytutu Prawa i Administracji PWSZ w Sulechowie, http://www.bibliotekacyfrowa.pl/ dlibra/info?forceRequestHandlerId $=$ true $\&$ mimetype $=$ application $/$ pdf $\&$ se$\mathrm{c}=$ false $\&$ handler $=$ pdf_browser\&content_url $=/$ Content $/ 34651 / 002 . p d f$ (27.07.2013).

[3] Carbo-Valverde S., Marques-Ibanez D., Fernandez F. R., Securitization, Bank Lending and Credit Quality. The Case of Spain, Working Paper Series no1329, European Central Bank, April 2011.

[4] Chaney T., Emrat P., US vs. European Housing Markets, HousingEconomics. com, National Association of Home Builders, http://www.nahb.org/generic. aspx?genericContentID $=57411$ \&print $=$ true $(19.05 .2013)$. 
The institutional matrices theory as the basis of explanation of real estate bubble

[5] Chmielewski P., Homo agens. Instytucjonalizm w naukach spolecznych, Poltext Sp. z o.o., Warszawa 2011, pp. 96-253.

[6] Coase R.H., The New Institutional Economics, "Journal of Institutional and Theoretical Economics” 1998, Vol. 140, pp. 230-231.

[7] Commons, Legal Foundations of Capitalism, Madison, Milwaukee, The University of Wisconsin Press, London 1968, pp. 5-8.

[8] Dietz R., Siniavskaia N., Who benefits from the bousing tax deductions?, HousingEconomics.com, National Association of Home Builders, http:// www.nahb.org/generic.aspx?genericContentID = 150471\&channelID = 311 (19.05.2013).

[9] Duca J.V., Muellbauer J., Murphy A., Credit standards and the bubble in US bouse prices: new econometric evidence, http://www.bis.org/publ/bppdf/ bispap64n.pdf (23.07.2013).

[10] European Mortgage Federation (EMF), Factsheet Poland 2009, http://www. hypo.org/content/default.asp?PageID=420 (09.11.2013).

[11] European Mortgage Federation (EMF), Factsheet Spain 2012, http://www. hypo.org/content/default.asp?PageID=420 (09.11.2013).

[12] European Mortgage Federation (EMF), Hypostat 2011, A Review of Europe's Mortgage and Housing Markets, http:/www.hypo.org/Content/Default.asp, (9.11.2013).

[13] Fannie Mae, Freddie Mac, http:/www.fanniemae.com, (09.06.2013), http:// www.freddiemac.com (09.06.2013).

[14] Garber P.M., Famous First Bubbles: The Fundamentals of Early Manias, MIT Press, London 2001, pp. 4-5.

[15] Gill K., What is Fannie Mae and Freddie Mac. Understanding The Nation's Lending System, http://uspolitics.about.com/od/economy/a/fannie_mae.htm (09.06.2013).

[16] Hardaway R.M., The Great American Housing Bubble. The road to collapse, Praeger, USA 2011, pp. 92-194.

[17] Hodgson M.G., What Are Institutions?, "Journal of Economic Issues" 2006, vol. XL, no. 1, pp. 2-3.

[18] http://www.aplaceinthesun.com/news/feature/tabid/131/EntryId/575/ Default.aspx (23.07.2013).

[19] http://www.knf.gov.pl/Images/sekurytyzacja_tcm75-4773.pdf (27.07.2013).

[20] http://www.kredyt-lider.pl/aktualnosci,aktualna-lista-bankow-z-najwyzszymltv,38.html (10.06.2013).

[21] http:/www.spanishpropertyinsight.com/2009/10/14/spanish-mortgage-taxrelief-to-go-in-2011-making-average-home-21000-euros-more-expensive/ (09.11.2013). 
[22] Kirdina S., A shift in the prevailing institutional models of the global order: is a new cycle starting?, "Munich Personal RePEc Archive" 2012, Paper No. 42999, electronic document available on: http://ideas.repec.org/p/pra/ mprapa/42999.html (10.04.2013).

[23] Kirdina S., From Marxian School of Economic Thought to System Paradigm in Economic Studies: The Institutional Matrices Theory, "Montenegrin Journal of Economics" 2012, vol. 8, no. 2, pp. 60-65.

[24] Kirdina S., Institutional Matrices and Institutional Changes, "Munich Personal RePEc Archive" 2003, Paper No. 29691, electronic document available on: http:// www.kirdina.ru/index.php?option $=$ com_content $\& v i e w=\operatorname{article} \& i d=211$ (15.05.2013).

[25] Kirdina S., Standstorm G., Institutional matrices theory as a framework for both western and non-western people to understand the global village, "Munich Personal RePEc Archive" 2010, Paper No. 18642, electronic document available on: http://mpra.ub.uni-muenchen.de/18642/ (20.05.2013).

[26] Kołodko G.W., Neoliberalizm i systemowy kryzys nowej gospodarki, in: Globalizacja, kryzys i co dalej?, Poltext, Warszawa 2010, pp. 93-94.

[27] Komisja Nadzoru Finansowego, http://www.knf.gov.pl/regulacje/praktyka/ rekomendacje/rekomendacje.html.

[28] Kornai J., Economics of Shortage, Amsterdam: North Holland, 1980.

[29] Kornai J., Resource-Constrained versus Demand-Constrained System, "Econometrica" 1979, no. 47, pp. 801-819.

[30] Kornai J., The Soft Budget Constraint, "Kyklos" 1986, vol. 39, pp. 4-6.

[31] Krugman P., Powrót recesji. Kryzys roku 2008, Wolter Kluwer Polska Sp. z o.o., Warszawa 2012, pp. 147-148.

[32] Ligon J., Beach W., Housing Market Without Fannie Mae and Freddie Mac: Economic Effects of Eliminating Government-Sponsored Enterprises in Housing, http://www.heritage.org/research/reports/2013/01/a-housing-market-free-of-fannie-mae-freddie-mac\#_ftn11 (21.04.2013).

[33] Mansharamani V., Boombustology: Spotting Financial Bubbles Before They Burst, John Wiley \& Sons, Inc., Hoboken, New Jersey 2011, pp. 178-179.

[34] North D.C., Institutions. Institutional Change and Economic Performance, Cambridge University Press, Cambridge, NY 1990, pp. 3-4.

[35] Paździor A., Kryzys finansowy i jego skutki dla gospodarki Polski i świata, Difin SA, Warszawa 2013, pp. 58-60.

[36] Soros G., Kryzys kredytowy 2008 i co to oznacza. Nowy paradygmat rynków finansowych, MT Biznes Sp. z o.o., Łódź 2008, pp. 135-136.

[37] Tyc W., Wartość jako metafizyczna idea myśli ekonomicznej, in: Prace Naukowe Uniwersytetu Ekonomicznego we Wrocławiu nr 139, Wydawnictwo UE we Wrocławiu, Wrocław 2010, pp. 11-26. 
[38] Veblen T.B., Teoria klasy próżniaczej, PWN, Warszawa 1971, pp. 171-173

[39] Waszkiewicz A., Sekurytyzacja w Polsce - trudna droga do sukcesu, http:// www.wsz-pou.edu.pl/biuletyn/?strona=biul_waszk14 (27.07.2013).

[40] Wiedemer D., Wiedemer R., Spitzer C., Januszen E., America's Bubble Economy: Profit When It Pops, John Wiley \& Sons, Inc., New Jersey 2006, p. 6.

[41] Williamson O. E., Markets and Hierarchies: Some Elementary Consideration, "American Economic Review" 1973, vol. 63, no. 2, p. 316. 